\title{
COVID-19 and Elderly Females—a Study of Social Representations in Brazil
}

\author{
Andréia Isabel Giacomozzi ${ }^{1}$ (iD $\cdot$ Adriano Rozendo ${ }^{2}$ (D) \\ Andréa Barbará da Silva Bousfield ${ }^{1}$ (D) Maiara Leandro ${ }^{1}$ (D) . \\ Juliana Gomes Fiorott ${ }^{1}$ (D) Anderson da Silveira ${ }^{3}$
}

Accepted: 24 June 2021

(c) Associação Brasileira de Psicologia 2022

\begin{abstract}
This study investigates psychosocial aspects related to preventive behavior and social representations (SR) of COVID-19 for elderly females. The method used to understand these features was an online questionnaire for 326 women over 60 years old. In general, participants are afraid of COVID-19, believe that may kill them, and perceive that they do not venture themselves much. They consider themselves to be moderately informed about COVID-19. Right-winged participants believed more in the hydroxychloroquine efficacy with a greater belief that viruses and diseases may have been manufactured by organizations. Left-winged participants believe more in the truth of media information and also have a greater belief in science. Concerning the SR of COVID-19, a possible central core was observed around the following elements: fear, isolation, suffering, and danger. The conclusion is that there is an intense political polarization around the theme due to the political positioning of the participants
\end{abstract}

Keywords Social representations $\cdot$ Elderly $\cdot$ Political polarization $\cdot$ COVID-19

\section{COVID-19 e mulheres idosas - Um estudo de Representações Sociais no Brasil}

\section{Resumo}

Este estudo investigou aspectos psicossociais relacionados à comportamentos de prevenção, e as Representações Sociais (RS) da COVID-19 para mulheres idosas

\footnotetext{
Translated by members of the Voluntary translation of informative materials related to COVID-19 project, offered by NUPEL/UFBA and supervised by professors M. Daniel Vasconcelos B.

Oliveira, Dr. Feibriss Henrique Meneghelli Cassilhas, Dr. Lucielen Porfirio, and Dr. Monique Pfau. Translators: Dara Lanzotti Sampaio and Maria Oliveira Boaventura dos Santos.
}

Andréia Isabel Giacomozzi

agiacomozzi@hotmail.com

Extended author information available on the last page of the article 
no Brasil. Para isso, utilizou-se questionário online com 326 mulheres com mais de 60 anos. As participantes acreditam que a COVID-19 pode matar, sentem medo, e percebem que se arriscaram pouco. Elas se consideraram medianamente informadas sobre COVID-19, sendo que as de direita acreditam mais na eficácia da hidroxicloroquina e têm maior crença de que vírus e doenças podem ser fabricados por organizações. As de esquerda acreditam mais na veracidade das informações da mídia e também têm maior crença na ciência. Sobre as RS da COVID-19, observou-se um possível núcleo central em torno de elementos: medo, isolamento, sofrimento e perigo. Conclui-se que houve intensa polarização política em torno da temática, visto que o posicionamento das participantes determinou uma série de aspectos que influenciam nas práticas preventivas frente a doença.

Palavras-chave Representações Sociais · Idosos · Polarização política · COVID-19

\section{COVID-19 y mujeres ancianas - Un estudio de Representaciones Sociales en Brasil}

\section{Resumen}

Este estudio investigó aspectos psicosociales relacionados con conductas de prevención y Representaciones Sociales (RS) y COVID-19 para mujeres mayores en Brasil. Se utilizó un cuestionario online con 326 mujeres mayores, con más de 60 años. Ellas creen que COVID-19 puede matar, tienen miedo, se dan cuenta de que tomaron pequeños riesgos y consideran que están moderadamente informadas acerca de COVID-19. Las mujeres de la derecha creen en la eficacia de la hidroxicloroquina y que las organizaciones pueden fabricar virus y enfermedades. Las que son de izquierda confían más en las informaciones publicadas y también confían en las descubiertas de la ciencia. Acerca de la RS de COVID-19, se observó un posible núcleo central alrededor de elementos: miedo, aislamiento, sufrimiento y peligro. Se concluye que hubo una polarización política acerca del tema, ya que el posicionamiento de los participantes determinó algunos aspectos influyen a las prácticas preventivas frente a la enfermedad.

Palabras clave Representaciones sociales $\cdot$ Personas mayores · Polarización política $\cdot$ COVID-19

\section{Introduction}

According to the World Health Organization (WHO), the world is going through a global pandemic caused by the novel coronavirus (SARS-CoV-2), which triggers a disease called COVID-19.

According to the specialized literature, the most common symptoms are temperature above $37{ }^{\circ} \mathrm{C}$ ( or $98.6{ }^{\circ} \mathrm{F}$ ); cough; fatigue; shortness of breath; muscle and joint pain; sore throat; headache; nausea; a reduced sense of smell and taste; 
among others (Nunes et al., 2020). The advanced stage of the disease can lead the victim to severe pneumonia; acute respiratory distress syndrome; sepsis; septic shock; and death. However, some infected individuals can be asymptomatic or develop some symptoms similar to regular flu (Brasil, 2020). The most prone group to develop more severe symptoms are recognized as "risk groups": people with hypertension, cardiovascular disease, cerebrovascular disease, and the elderly, considering here people aged sixty years old or more (Liu et al., 2020).

In Brazil and other countries, the advance of the pandemics and the increase in the number of cases and deaths make people develop specific feelings such as anguish, uncertainty with the unknown, anxiety, and panic. According to WHO (2020) information, these feelings impact people's daily behavior and can cause a range of social implications, namely, supermarket looting, agglomeration, lack of hygiene, and preventive care according to official recommendations, among others. In that sense, Brooks et al. (2020) report, from a literature review of 24 previous quarantine experiences, that the most common symptoms experimented by people in social isolation are the following: anxiety; symptoms of post-traumatic stress disorders; confusion; anger; psychological suffering; depression; lack of humor; irritability; sleeplessness; emotional exhaustion; fear; frustration; boredom; sadness; and guilt. These symptoms were similarly detected during the COVID-19 isolation measures, mainly between elderly populations. This situation motivated experts to promote mental health strategies for this group during the pandemics (Nunes et al., 2020).

Lima et al. (2020) observed that the elderly became a risk group not only because of their biological characteristics (such as immunosenescence and the higher incidence of chronic disease), but also their belief systems. Even for elderly women, who believe in their higher risk susceptibility, negligent behavior during the social distancing and isolation period has been shown. In contrast to what science and the experts have warned, the elderly believe that they have a medium contamination risk (Lima et al., 2020). For that reason, we consider the investigation of the female gender intersection important. In other words, we understand that women tend to be more attentive to health self-care, but due to the elderly age range, they also tend to loosen their risk perception.

Therefore, we consider an important theoretical assumption that preventive behavior related to a disease is influenced both by a behavioral dimension and by a value system related to the sociocultural dimension. Human behaviors are forged in a network of symbolic associations and built throughout history. Such behaviors and their meanings are transmitted to individuals through their reference groups. That is why old social practices are difficult to modify, as they are adopted and perceived as normal, rational, or natural, even when they could potentially expose people or groups to risks (DaMatta, 1987). Therefore, in order to understand the aspects involved in the preventive behavior to deal with COVID-19, it is necessary to use theoretical assumptions that make it possible to articulate the understanding of the various factors of influence and behavioral adherence, such as the social representation (SR) theory and risk conceptions and perceptions. 


\section{Risk and Risk Perception}

Other important elements to be considered whether adhering or not to social exclusion and isolation measures are risk and risk perception towards the disease. Risk is subjective in nature and represents a mixture of scientific content and important psychological, social, cultural, and political factors. Consequently, the risk perception must be examined based on the opinions that individuals experience when they must, in different ways, evaluate the technologies, substances, or activities with more or less risks (Chauvin \& Hermand, 2006).

There are several aspects that influence people's risk perception, which can be divided into sociodemographic and psychosocial variables. According to Chauvin and Hermand (2006), the main sociodemographic variables involve gender, age, education level, profession, income, and political orientation. The psychosocial variables are media exposure, influence of the worldview, anxiety, and others. For example, the women's risk perception tends to be higher than that of men. Another example is that less-educated individuals globally perceive themselves to be at greater risk than more educated individuals.

In the special case of coronavirus, studies have drawn attention to some important aspects related to the prevention of contamination, such as political position (Eicher \& Bangerter, 2015; Taylor, 2019; Plohl \& Musil, 2020), orthodox religiosity (Plohl \& Musil, 2020), conspiratorial thinking (Eicher \& Bangerter, 2015; Taylor, 2019), confidence in science, and compliance with the preventive rules suggested by health institutions (Plohl \& Musil, 2020). Based on these previous studies, we therefore consider the investigation of such aspects with this specific group of elderly women through the pandemics an important contribution to the field.

\section{Political Belonging, Sources of Information, and Social Representations}

Among the aspects related in the previous section, the political position seems to be accentuated at this moment in Brazil. In the past years, the country has been going through an evident political polarization (Giacomozzi et al., 2019) which has severely split the social groups. Thus, the anchorage of a new social object, such as COVID-19, is determined by the socio-normative meta-system that organizes the life of each group. Moscovici (1981) observes that the images, concepts, and languages shared by a given social group will determine the angle from which it will handle an unfamiliar situation.

In This Sense, Different Social Groups Prefer Different Sources of Information. Since the intense criticism that media and science have been suffering from the right-wing political groups in Brazil, it is expected that such groups will prefer other sources of information, such as alternative media or TV channels aimed at this audience. In the same way, different writers and media information vehicles will choose different anchoring categories for a social object (Castro \& Gomes, 2005). Their chosen categories will emit different universes of meanings and will make progress in society along different paths. 
Media play an important role in disseminating scientific knowledge to a large part of the population. In this context, the social representation theory (Moscovici, 1978) has contributed to understanding how different social groups acquire and share knowledge considering that social representations privilege some conduct and communication vehicles over others. Human conduct is not rooted in abstract rationality or an isolated action. It is the expression of a complex synthesis to a specific object whose meaning is attributed by individuals in their social relations that articulates information, values, symbols, habits, necessities, interests, images, and desires. Thus, in order to apprehend the social representations of an object, we must observe the space where the individual communicates and acts (Jodelet, 2001).

Therefore, influential factors to prevent COVID-19 are a social and individual phenomenon at the same time, since such practices are both the object of a personal experience and re-elaborated discussions from the media and the social groups that one belongs to.

The fact is that the main preventive action against new infections is social behavior. Behavior is how social groups will avoid transmitting the disease. In this sense, behavior is an important study object to social psychology, especially to social representation theory (SRT) considering that it focuses on common sense knowledge; belief systems; the groups and individual's perception (including risks); and the attitudes about the social objects as COVID-19. All of this information is related to social representations (SRs), which are interpretations of realities that transform the technical-scientific knowledge in a daily knowledge by process of anchorage and objectification (Moscovici, 1961/2012). Social representations play an important role in social practices (Jodelet, 2001).

According to Abric (1998), SRs have four essential functions: knowledge, identity, guidance, and justificatory. Knowledge because it gives knowledge to the individual so that they can assimilate and interact with their values and beliefs. Identity works when one has similar thoughts as a given group and therefore feels part of it, allowing the protection of each group's specificities by defining its identity. Guidance means SRs also serve as a guide for behavior and social practices; that is, it is a guide for action. Justificatory means, as a guide, SRs justify behaviors and actions (Abric, 1998).

Furthermore, SRs have real status in the specific contexts of groups and individuals considering that they guide beliefs, attitudes, and behaviors (Moscovici, 1961/2012). Thus, SRs are directly related to risky or preventive social behaviors. A SR study on COVID-19 pointed to the trend of anchoring the novel coronavirus in past diseases with the election of heroes (health professionals) or villains (journalists, government officials, etc.), blaming immigrant populations-the risk associated with the other-which points to a strong trend towards the politicization of the disease (Páez \& Pérez, 2020). According to Castro and Gomes (2005), this situation happens in the circulation and recycling of common sense contents, the old constantly reappears in the new. In other words, new objects are understood through the lens of the old, in the complex transformations that common sense suffers from communication. 
Based on the above considerations, we believe that verifying elderly women's SR, their preventive behaviors, and perception on COVID-19 become relevant for academic, social, sanitary, administration, and public health interests, as well as other related spheres

\section{This Study}

This study investigates and understands elderly women's SRs about COVID-19, as well as the preventive practices that the group adopts for the disease and its relation with the risk perception and other related psychosocial aspects (namely, sources of information, sense of informational level, religion, political positioning, fear, among others).

\section{Method}

This is an exploratory-descriptive and comparative study. Our data were collected and analyzed from a self-administered questionnaire through online sources, shared on WhatsApp groups: an invitation to elderly women throughout Brazil to participate in the research.

\section{Instruments}

The research instrument contained open and closed items based on previous research (Plohl \& Musil, 2020; Lima et al., 2020) about the theme. The questionnaire counted on 21 questions, covering the following topics: (a) sociodemographic data; (b) social representations through an evocation test with the inductive stimulus "COVID-19"; (c) beliefs and knowledge about the disease; (d) preventive behaviors; (e) sources of information; (f) risk perception; and ( $\mathrm{g}$ ) other variables that may be associated with practices due to the disease, such as religiosity, conspiratorial thinking, education, and political positioning.

\section{Data Analysis}

We performed a descriptive and relational statistical analysis using closed-ended questions with the Statistical Package for the Social Sciences software assistance (SPSS-17.0.). The answers to the word evocation questions were analyzed with the IraMuTeQ assistance software. For textual data analysis (Ratinaud \& Marchand, 2015), we used prototypical analysis. This way, our analysis of the material collected in the evocation test considered the individual (frequency) and collective (average evocation order) spheres providing the identification of the centrality of representation elements (Wachelke et al., 2016). 


\section{Results}

For our analysis, 326 women over 60 years old participated: $40.8 \%$ between 60 and 64 years old; $29.8 \%$ between 65 and 70 years old; $18.1 \%$ between 70 and 74 years old; $7.1 \%$ between 75 and 79 years old; $3.4 \%$ between 80 and 84 years old; and $0.9 \%$ over 85 years old. Most of them (44\%) reported to live in the Southeast Region of Brazil, 33.75\% in the South, $12.80 \%$ in the Northeast, $7.5 \%$ in the Central-West, and $0.95 \%$ in the North. Concerning education, $37.7 \%$ of the participants have higher education, $31.3 \%$ have postgraduate education, $13.8 \%$ completed high school education, $10.1 \%$ did not complete higher education, $3.1 \%$ did not complete high school, $2.5 \%$ did not complete elementary school, and $1.5 \%$ completed elementary school.

Regarding religion, $55.2 \%$ stated to be catholic, $16.3 \%$ spiritist, $9.5 \%$ "other religions," $8.3 \%$ "no religion," 5.8\% evangelical, $2.1 \%$ agnostic, $1.8 \%$ atheist, and $0.9 \%$ from Afro-Brazilian religions.

The fact that the largest proportion of participants are Catholics and high schooling made it impossible to compare risk perception, fear and also the SR about COVID-19 for these variables. Still, the literature points out that these variables are important for adherence to preventive practices.

\section{Risk, Fear, and Preventive Practices}

Using a Likert 5-point scale, the sample had a high average in the index if it considers the risk groups $(\mathrm{M}=4.33 ; \mathrm{SD}=0.86)$ and this seems to make sense as they got a low average in the item "to have risked" towards the disease $(\mathrm{M}=2.77 ; \mathrm{SD}=1.07)$.

About the new habits adopted during the quarantine, $95.4 \%$ of the participants stated to have changed their hygiene habits because of COVID-19. Regarding the belief that COVID-19 can kill, the general average was high $(\mathrm{M}=4.45 ; \mathrm{SD}=0.68)$. It was also high in relation to the fear of being infected $(\mathrm{M}=4.26 ; \mathrm{SD}=0.90)$.

About the adopted preventive practices, the most reported one (73\%) was to stay at home in quarantine and leave just in case of emergencies. The second most reported was to keep distance from people in the street, at the supermarket, or banks (53.7\%). Only two participants stated that they did not adopt any preventive practices; they said that they do not isolate themselves and lead a normal life, with no change in the routine at all.

\section{Political Positioning and Information on COVID-19}

Regarding political positioning, 34.4\% said they were not interested in politics, $29.4 \%$ are from the right-winged, $26.7 \%$ left-winged, $8 \%$ center, $0.9 \%$ extreme left-winged, and $0.6 \%$ extreme right-winged. In order to compare the averages, we summed the left-winged and extreme left-winged categories, as well as right-winged with extreme right-winged categories. From that sum, $34.4 \%$ of the participants are not interested in politics, $30.1 \%$ are right-winged, $27.6 \%$ are left-winged, and $8 \%$ 
are in the center. Comparisons of averages were always performed using the rightand left-winged groups as references, as they understand that they are supposedly in opposition regarding the investigated variables.

In respect to those who consider themselves well informed about COVID-19, we obtained a general average above the average $(\mathrm{M}=3.69$; $\mathrm{SD}=0.75)$ on the 5-point scale, with the left-winged participants having a slightly higher average $(\mathrm{M}=3.95$, $\mathrm{SD}=0.70)$ than the right-winged participants $(\mathrm{M}=3.69, \mathrm{SD}=, 77)$, with no statistically significant differences between the averages.

Regarding the participants' sources of information about COVID-19, we offered several options and it was possible to select more than one. The participants stated that they usually receive information from doctors and health professionals (65.3\%), from the traditional media (TV, newspapers, radio, and magazines-58.3\%), from scientific papers $(54.6 \%)$, from government agencies (the Ministry of Health, Health Surveillance, etc.-44.2\%), from social networks on the internet (WhatsApp/Facebook/Twitter/YouTube/Instagram-33.1\%), and from friends or family (13.2\%). The participants who declared to receive information from doctors and health professionals were mostly left-winged (74.4\%), and $55.1 \%$ were right-winged. In respect to traditional media, it was well asked which TV channel they prefer to receive information on COVID-19. From the left-winged group, $47.8 \%$ said they prefer to watch Globo Television Network, and $18.9 \%$ said they did not get information on COVID19 through TV. For the center group, $46.2 \%$ watch Globo Television Network and $38.5 \%$ do not get information through TV. For the right-winged group, $31.6 \%$ do not get information through TV, and $24.5 \%$ watch TV Record. Finally, for the group that is not interested in politics, $27.9 \%$ are informed through Globo Television Network and $24.5 \%$ do not get information through TV. There was a statistically significant association between the variables, demonstrating that the political position interferes with the preference for certain TV channels to receive information about the disease $\left[x^{2}=107.18 ; \mathrm{gl}=30 ; \mathrm{p}=000\right]$.

Regarding the belief in the efficacy of hydroxychloroquine in the treatment of COVID-19, the average for the right-winged group was much higher $(M=4.28$; $\mathrm{SD}=0.89)$ than the average for the left-winged group $(\mathrm{M}=1.51 ; \mathrm{SD}=0.64)$. The difference between the averages was $2.77(\mathrm{t}(186)=24.22 ; \mathrm{p}<.000)$ showing that right-winged political participants believe much more in the effectiveness of this medicine against COVID-19.

Concerning the belief in the information conveyed by the media, the average of the group on the left-winged was higher $(\mathrm{M}=4.48 ; \mathrm{SD}=0.65)$ than that of the group on the right-winged $(\mathrm{M}=3.52 ; \mathrm{SD}=1.04)$. The difference between the average was $0.97(\mathrm{t}(186)=7.51 ; \mathrm{p}<.000)$, showing that left-winged participants believe more that the media information about COVID-19 is true.

Finally, in respect to believing in science and specialists such as doctors, there were also differences, since the average of the left-winged group was higher $(\mathrm{M}=$ 4.48; $\mathrm{SD}=0.65)$ than that of the right-winged group $(\mathrm{M}=3.52 ; \mathrm{SD}=1.04)$. The difference between the average was $0.96(\mathrm{t}(186)=7.51 ; \mathrm{p}=000)$.

In addition, with regard to the results on how much the participants trust in the Brazilian president's statements about COVID-19, the average for the left-winged group was much lower $(\mathrm{M}=1.01 ; \mathrm{SD}=0.10)$ than the for the right-winged group 
$(\mathrm{M}=3,84 ; \mathrm{SD}=1.16)$. The difference between the averages was $2.83(\mathrm{t}(186)=$ 23.8; $\mathrm{p}=000)$.

In regard to believing that the dissemination and spread of viruses or diseases are created by organizations or countries, the groups also presented differences, since the average of the left-winged group was much lower $(\mathrm{M}=1.54 ; \mathrm{SD}=0.96)$ than that of the right-winged group $(\mathrm{M}=3.21 ; \mathrm{SD}=1.31)$. The difference between the averages was $1.66(\mathrm{t}(186)=9.88 ; \mathrm{p}=000)$.

\section{Social Representations About COVID-19}

We requested the participants to write the first three words that came to their minds when they think about COVID-19. We obtained 941 words. From this result, 148 words were different and, for our analysis, we considered those whose frequency was higher than 4 . Our corpus analysis was assisted by the IRaMuTeq-Interface de R pour les Analyses Multidimensionnelles de Textes et de Questionnaires software (Ratinaud, 2009). In the prototypical analysis, the SR structure constitution of COVID-19 appears through the most frequent elements and those most likely to belong to the central core, while the less frequent elements and late evoked represent the periphery of social representation (Wachelke et al., 2016). Table 1 represents the elements that the participants used to describe the disease.

The upper left quadrant of the table shows where the representations of possible central elements of COVID-19 are for the participants because they are more frequent and more readily evoked. In this study, the most evocative elements were as follows: fear (91), social isolation (81), and disease (21). The former (disease) obtained a higher activation compared to the others $\mathrm{AOE}=1.3$. Elements such as pandemics, mask, suffer, virus, insecurity, and danger were also important for the group revealing the SR of COVID-19, which is mainly associated with fear in relation to the disease, and also to the social practices necessary to prevent contagion.

In the upper right quadrant is the 1st periphery. These elements are peripheral probably because they have a high degree of activation. The words are death, care, hygiene, concern, and prevention.

The lower left quadrant is the 2nd periphery, or contrast zone, because it has the least evoked elements, but they were promptly mentioned. Both peripheral quadrants (1st and 2nd) are related and support the central core of the representation. Meanwhile, different from the core, these quadrants are more flexible and changeable because they are associated with the immediate context in which people are, or sub-groups within this bigger group. On the 2nd periphery, the words are quarantine, China, shortness of breath, ICU, fever, and severe.

Finally, the last, lower right quadrant is the contrast zone, which is constituted by more distant elements due to a lower frequency and lower readiness. In this quadrant, the words are contagious, sadness, hope, health, anxiety, stay at home, hospital, politicization, pain, and risk.

A similarity analysis was also carried out in order to verify co-occurrences between the words and their variables. For this study, the variable 
Table 1 Diagram of quadrants of SR about COVID-19

\begin{tabular}{|c|c|c|c|c|c|c|}
\hline & \multicolumn{3}{|l|}{$\mathrm{AOE} \leq 1.87$} & \multicolumn{3}{|l|}{$\mathrm{AOE} \leq 1.87$} \\
\hline & Element & $\mathrm{F}^{*}$ & OME* & Element & $\mathrm{F}$ & OME \\
\hline \multirow{9}{*}{$f \geq 15.81$} & Fear & 91 & 1.5 & Death & 78 & 2 \\
\hline & Social isolation & 81 & 1.8 & Care & 38 & 2 \\
\hline & Disease & 21 & 1.3 & Hygiene & 19 & 2.2 \\
\hline & Pandemic & 20 & 1.7 & Concern & 18 & 2.1 \\
\hline & Mask & 20 & 1.8 & Prevention & 17 & 2.1 \\
\hline & Suffer & 19 & 1.8 & & & \\
\hline & Virus & 19 & 1.4 & & & \\
\hline & Insecurity & 17 & 1.6 & & & \\
\hline & Danger & 16 & 1.8 & & & \\
\hline \multirow[t]{10}{*}{$\mathrm{f} \geq 15.81$} & Quarantine & & & Contagious & 14 & 2.1 \\
\hline & China & & & Sadness & 14 & 2.1 \\
\hline & Shortness of breath & & & Hope & 11 & 2.6 \\
\hline & ICU & & & Health & 11 & 2.2 \\
\hline & Fever & & & Anxiety & 10 & 2.6 \\
\hline & Severe & & & Stay at home & 9 & 2.1 \\
\hline & & & & Hospital & 8 & 2.1 \\
\hline & & & & Politicization & 7 & 2.1 \\
\hline & & & & Pain & 7 & 1.9 \\
\hline & & & & Risk & 6 & 2 \\
\hline
\end{tabular}

Note: $* F$, frequency of evocation; $* * A O E$, average order of evocation

political positioning was analyzed, as follows: "center-winged," "right-winged," "left-winged," and "I have no interest in politics" (Figure 1).

On one hand, the "right-winged" participants show positions tied to words that point out the dangers of the disease, such as the following: death, danger, suffering, ICU, but they also point out political aspects linked to the pandemics, with the following elements: politicization and China. On the other hand, the positioning of the "left-winged" group points to elements linked to the virus itself and related practices: pandemics, risk, health, and quarantine. The positioning of the "centerwinged" group goes towards the feelings with the following words: fear, concern, insecurity, and anxiety. Lastly, the "I have no interest in politics" group was related to the following words: social isolation, hygiene, prevention, mask, pain, care, sadness, disease, virus, and hope.

\section{Discussion}

This study investigated and understood elderly women's SRs in relation to COVID19 as well as the preventive practices that the group adopts to deal with the disease and their relation with risk perception and sources of information about it. It is noteworthy that the group of participants has a very high level of education when 


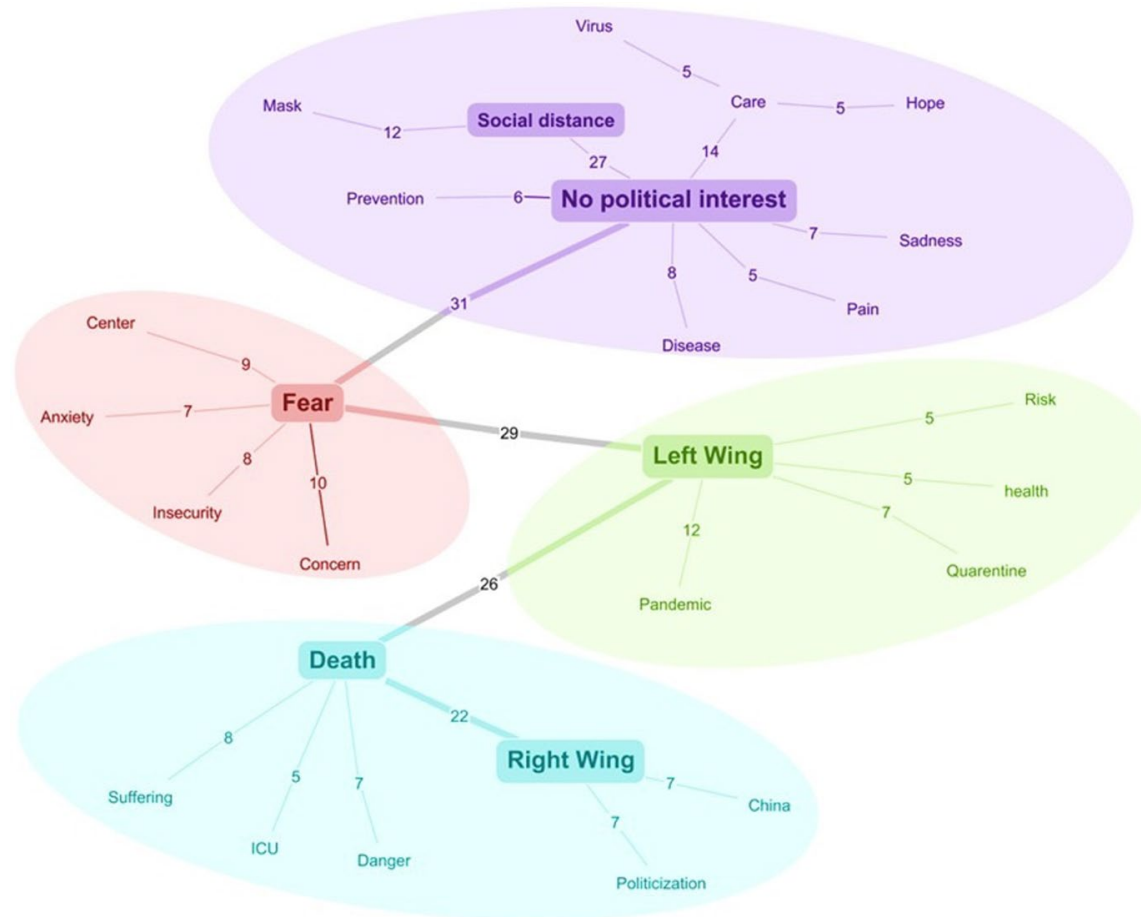

Fig. 1 Similitude analysis by political belonging

compared to the general level of the Brazilian population-37.7\% of the participants have higher education and $31.3 \%$ have a postgraduate degree. The proportion of Brazilian adults and elderly people who have completed high school is $48 \%$, with only $17.4 \%$ of the population having completed higher education (IBGE, 2019).

The average rate of participants who considered themselves to be in the risk group was high and the average rate of participants who had risked themselves towards the disease was low. This is important because studies show that when people have a high perception of risk for certain diseases, they are more likely to have preventive behaviors against them (Lau et al., 2007; Maughan-Brown \& Venkataramani, 2017).

In addition, we observed that a large part of the elderly participants changed their hygiene habits due to COVID-19. They also believe that the disease can kill and are afraid of becoming infected. The changes in hygiene habits and other changes were necessary for the entire population, especially for the elderly, as they are considered the most at-risk population group (Liu et al., 2020). The WHO provided specific guidelines for the elderly population, which resulted in booklets and informational materials aimed at encouraging new habits, care, and prevention practices (Nunes et al., 2020).

There are different factors that influence preventive practices and approaches to COVID-19. The transformations resulting from the pandemics and the adherence or not to new habits and practices of care can vary according to the subjects' 
belief system (Lima et al., 2020). This situation was possible to observe in this study because the participants mentioned beliefs associated with fear of death and infection.

Most of the research participants considered themselves informed about COVID19. The main sources of information were doctors and health professionals, the traditional media, scientific studies, government agencies, social networks, and friends or family. Media vehicles spread news in different directions, and digital platforms are of great importance, as they provide the population with access to real-time information on the numbers of deaths and recovered people, disseminating recommendations related to preventive strategies and the need for social distance (Paula \& da Silva Mello, 2020).

Regarding the political position, we identified that the groups resulted in different averages, indicating that the participants in the right-winged political position believe considerably more in the efficacy of the drug hydroxychloroquine to treat COVID-19 patients, even though its efficacy is not scientifically proved (Menezes et al., 2020; Souza et al., 2020). That drug was widely defended by the current president of Brazil, who in his speeches also denied or minimized the risks of the disease (Ferraz, 2020; Tavares et al., 2020). Therefore, the dichotomy among the use or not of hydroxychloroquine has become a demand that pervades political issues, as well as it involved the polarization between left-winged and right-winged Brazilian citizens. It demarcates a feeling of belonging to a group and a sense of identification, for the members of the other group, which group one belongs to. It has become a matter of metaknowledge (Elcheroth et al., 2011; Wagner, 1995) on the SR content and value between the "I" and the other and its informational polarization in Brazil about COVID-19 (Justo et al., 2020). On the one hand, scientists and health professionals were providing some kind of information (for example, pro-social isolation practices and the ineffectiveness of hydroxychloroquine); on the other hand, the president of Brazil issued a contrary position through his behavior and social network.

Through the SRs, communication does not only happen for the in-group-those belonging to the same political side in this case; it is also aimed at the outgroup considering that interaction between ego and alter is crucial for SR theories (Marková, 2007). As a fundamental feature, SRs are always directed at others, pointing something out to someone else and, more generally, expressing something to someone with whom one communicates. Thus, SRs are formed in and through dialogs (Moscovici, 1976) which favor the construction of the polemic SRs through the groups, as it stimulates polarization.

We also observed differences regarding the political position of the left-winged versus the right-winged groups concerning beliefs in the information conveyed by the media and science and in specialists such as doctors, in which the participants on the left-winged group presented a higher average. It is noteworthy that belief in science and specialists has been described in the literature as important factors in the adoption of preventive behaviors against diseases such as taking vaccines (Keelan et al., 2010). As expected, there was also a marked preference of participants for certain TV channels according to their political position. The idea that the press plays a central role in the dynamics of the thinking society was already present in the initial 
work of Moscovici (1961) and it was also possible to observe it in this study: different media vehicles choose different perspectives under which to analyze the same social phenomena, and from there, they will be chosen or passed over by certain groups (de Rosa et al., 2021).

In the analysis of how much the participants rely on the president of Brazil's words concerning COVID-19, the highest average was that from the right-winged group. This group also presented the highest in the item dedicated to measuring conspiracy thinking. Through the media, influential people have described COVID-19 as a biological weapon created by the USA (or China) to weaken China and the European Union (or to weaken the USA). Such conspiracy theories allude to the tendency to blame foreigners or powerful groups. The perception that the world is a dangerous place tends to be associated with conspiracy theories that underlie the belief that social and health interventions are only marginally effective (Eicher \& Bangerter, 2015; Taylor, 2019), which can harm behaviors to prevent certain diseases.

This research has highlighted the distinct features of social groups' political positions and how much they influence the participants' beliefs. The representational elements also differed in positioning, revealing that while the right-winged participants linked the pandemics to elements like "politicization" and "China," the left-winged participants evoked elements such as "risk" and "fear." It is also necessary to think that the participants who declared themselves as "I have no interest in politics" could access more practical elements focused on prevention, such as "mask" and "social isolation." Paez and Perez's (2020) study looked into the SRs about COVID-19 and verified the anchoring of COVID-19 representations in past diseases, different nationalities, unhygienic practices, and groups that diverted from the individualistic self-control ethos. This investigation can enlighten us in regard to socio-political relations, dynamics of common sense beliefs, and its relation to social behavior.

The Brazilian researchers Bú et al. (2020) investigated representations and social anchorages of the novel coronavirus and treatment of COVID-19 and identified that the genesis of social representations of COVID-19 consists of concerns associated with its dissemination and its psychosocial and affective implications. When analyzing social representations in different social groups, Do Bú et al. observed that SR variations are identified according to the groups. They reflect on the importance of considering the specificities of social groups in the dissemination of practices directed to pandemic control. We would also like to emphasize that as SRs are inseparable from their cultural, social, and political emergency matrix, their theorization is congruent with a critical lens of interpretation (Howarth, 2006).

So, the results of this research point to an intense political polarization around COVID-19 since the participants' political positioning determined the number of psychosocial aspects which ultimately influence preventive practices to deal with the disease, such as the belief in hydroxychloroquine, on media information, in experts, and in the president's discourses, and the strong presence of conspiracy thinking among the participants on the right-winged group. We were unable to compare the average of participants' religion and education background, because the predominant religion was catholic and the education 
background was generally high. The only variable that determined differences in the participants' averages and their SRs about COVID-19 was political positioning.

According to our theoretical framework, we argue that preventive practices against the novel coronavirus cannot be understood apart from social representations that shape its symbolic foundation. This situation happens because the experiences are not strictly individual and carry the common sense that informs people (Jodelet, 2006), as a subjective background to the practices (Negura, 2016). This way, experiences promote important information about the social mechanisms that inform the meanings attributed to circumstances and, regarding political positioning, $34.4 \%$ said they were not interested in politics, $29.4 \%$ are from the right-winged, $26.7 \%$ left-winged, $8 \%$ center, $0.9 \%$ extreme left-winged, and $0.6 \%$ extreme right-winged. In order to compare the averages, we summed the left-winged and extreme left-winged categories, as well as right-winged with extreme right-winged categories. From that sum, $34.4 \%$ of the participants are not interested in politics, $30.1 \%$ are right-winged, $27.6 \%$ are left-winged, and $8 \%$ are in the center. Comparisons of averages were always performed using the right- and left-winged groups as references, as they understand that they are supposedly in opposition regarding the investigated variables.

In respect to those who consider themselves well informed about COVID-19, we obtained a general average above the average $(\mathrm{M}=3.69 ; \mathrm{SD}=0.75)$ on the 5 -point scale, with the left-winged participants having a slightly higher average $(\mathrm{M}=3.95, \mathrm{SD}=0.70)$ than the right-winged participants $(\mathrm{M}=3.69, \mathrm{SD}=, 77)$, with no statistically significant differences between the averages.

At the same time, guide the resulting emotional reactions. Thus, SRT provides a way to understand the prevention practices in a global way. As a social thought process, it provides references to an individual to understand a complex social and cultural system where the basis of preventive practices against the novel coronavirus are.

Regarding political positioning, 34.4\% said they were not interested in politics, $29.4 \%$ are from the right-winged, $26.7 \%$ left-winged, $8 \%$ center, $0.9 \%$ extreme left-winged, and $0.6 \%$ extreme right-winged. In order to compare the averages, we summed the left-winged and extreme left-winged categories, as well as right-winged with extreme right-winged categories. From that sum, $34.4 \%$ of the participants are not interested in politics, $30.1 \%$ are right-winged, $27.6 \%$ are left-winged, and $8 \%$ are in the center. Comparisons of averages were always performed using the right- and left-winged groups as references, as they understand that they are supposedly in opposition regarding the investigated variables.

In respect to those who consider themselves well informed about COVID-19, we obtained a general average above the average $(\mathrm{M}=3.69 ; \mathrm{SD}=0.75)$ on the 5-point scale, with the left-winged participants having a slightly higher average $(\mathrm{M}=3.95, \mathrm{SD}=0.70)$ than the right-winged participants $(\mathrm{M}=3.69, \mathrm{SD}=, 77)$, with no statistically significant differences between the averages. 


\section{Final Regards}

In this study, we observed a strong influence of the participants' political positioning both in their SRs concerning COVID-19 and in their beliefs (science, health professionals, hydroxychloroquine efficacy, the president's discourses, and conspiracy thinking). These factors were therefore mediated by the women's different groups according to their political positioning.

Data Availability The datasets generated during and/or analysed during the current study are available from the corresponding author on reasonable request.

\section{Declarations}

Informed Consent Informed consent was obtained from all individual participants included in the study.

Conflict of Interest The authors declare that they have no conflict of interest.

\section{References}

Abric, J. C. (1998). A abordagem estrutural das representações sociais. Estudos interdisciplinares de representação social, 2(1998), 27-38.

Brasil. (2020). Ministério da Saúde: O que é coronavírus (COVID-19)? [site]. Retrieved from: https:// coronavirus.saude.gov.br/

Brooks, S. K., Webster, R. K., Smith, L. E., Woodland, L., Wessely, S., Greenberg, N., \& Rubin, G. J. (2020). The psychological impact of quarantine and how to reduce it: rapid review of the evidence. The Lancet, 395(10227), 912-920. https://doi.org/10.1016/S0140-6736(20)30460-8.

Bú, E. A. D., Alexandre, M. E. S. D., Bezerra, V. A. D. S., Sá-Serafim, R., \& Coutinho, M. D. P. D. L. (2020). Representações e ancoragens sociais do novo coronavírus e do tratamento da COVID-19 por brasileiros. Estudos de Psicologia (Campinas), 37, e200073. https://doi.org/10.1590/1982$0275202037 \mathrm{e} 200073$.

Castro, P., \& Gomes, I. (2005). Genetically modified organisms genetically in the Portuguese press: Thematization and anchoring. Journal for the Theory of Social Behaviour, 35(1), 1-17. https:// doi.org/10.1111/j.0021-8308.2005.00261.x.

Chauvin, B., \& Hermand, D. (2006). Influence des variables distales sur la perception des risques: une revue de la littérature de 1978 à 2005. Les cahiers Internationaux de Psychologie Sociale, 72, 65-84 Retrieved from: https://www.cairn.info/revue-les-cahiers-internationaux-de-psychologiesociale-2006-4-page-65.htm.

DaMatta, R. (1987). A casa e a rua: espaço, cidadania, mulher e morte no Brasil (6th ed.). Rocco.

de Rosa, A., Mannarini, T., Gil de Montes, L., Holman, A., Lauri, M., Negura, L., Giacomozzi, A., da Silva Bousfield, A., Justo, A., de Alba, M., Seidmann, S., Permanadeli, R., Sitto, K., \& Lubinga, E. (2021). Processos de criação de sentido e representações sociais de COVID-19 no discurso público multifacetado: exemplos ilustrativos de comunicação institucional e de mídia em dez países. Community Psychology In Global Perspective, 7(1), 13-53 Retrieved from: http://sibaese.unisalento.it/index.php/cpgp/article/view/22723.

Eicher, V., \& Bangerter, A. (2015). Social representations of infectious diseases. In G. Sammut, E. Andreouli, \& G. Gaskell (Eds.), Handbook of social representations (pp. 385-396). University Press.

Elcheroth, G., Doise, W., Reicher, S. (2011). On the knowledge of politics of knowledge: How a social representations approach helps us rethinking the subject of political psychology. Political Psychology, 32(5). https://doi.org/10.1111/j.1467-9221.2011.00834.x 
Ferraz, L. M. R. (2020). Saúde e política na crise da COVID-19: apontamentos sobre a pandemia na imprensa brasileira. Revista Eletrônica de Comunicação, Informação e Inovação em Saúde, 14(2). https://doi.org/10.29397/reciis.v14i2.2128.

Giacomozzi, A. I., Fiorott, J., \& Bertoldo, R. B. (2019). Violence as a result of political polarization: A media social study on Social Representations. In: 7th International seminar: political and economic self-constitution: media, citizenship activity and political polarization, 2019, Padova. Proceedings of the VII International scientific and practical seminar. Padova, 2019. p. 101-106. Retrieved from: http://www.pesc2019.org/

Howarth, C. (2006). A social representation is not a quiet thing: Exploring the critical potential of social representations theory. British Journal of Social Psychology, 45(1), 65-86. https://doi.org/ 10.1348/014466605X43777.

IBGE (2019). Pesquisa Nacional por Amostra de Domicílios Contínua - PNAD Contínua. Retrieved from: https://biblioteca.ibge.gov.br/visualizacao/livros/liv101736_informativo.pdf

Jodelet, D. (2001). Representações sociais: um domínio em expansão. In D. Jodelet (org.). As representações sociais. (pp. 17-44). EdUERJ.

Jodelet, D. (2006). Place de l'expérience vécue dans le processus de formation des représentations sociales. In V. Hass (Ed.), Les savoirs du quotidien. Transmissions, Appropriations, Représentations (pp. 235-255). Les Presses Universitaires de Rennes.

Justo, A.M., Bousfield, A.B.S., Giacomozzi, A. I., \& Camargo, B.V. (2020). Communication, social representations and prevention. The information polarization on COVID-19 in Brazil. Papers on Social Representations, Preprint. Retrieved from: http://psr.iscte-iul.pt/index.php/PSR/artic le/view/533/471

Keelan, J., Pavri, V., Balakrishnan, R., \& Wilson, K. (2010). An analysis of the human papilloma virus vaccine debate on MySpace blogs. Vaccine, 28(6), 1535-1540. https://doi.org/10.1016/j. vaccine.2009.11.060.

Lau, J. T. F., Kim, J. H., Tsui, H., \& Griffiths, S. (2007). Anticipated and current preventive behaviors in response to an anticipated human-to-human H5N1 epidemic in the Hong Kong Chinese general population. BMC Infectious Diseases, 7. https://doi.org/10.1186/1471-2334-7-18.

Lima, D. L. F., Dias, A. A., Rabelo, R. S., Cruz, I. D., Costa, S. C., Nigri, F. M. N., \& Neri, J. R. (2020). COVID-19 no Estado do Ceará: Comportamentos e crenças na chegada da pandemia. Ciência e Saúde Coletiva, 25(5), 1575-1586. https://doi.org/10.1590/1413-81232020255.07192 020 .

Liu, K., Chen, Y., Lin, R., \& Han, K. (2020). Clinical features of COVID-19 in elderly patients: A comparison with young and middle-aged patients. Journal of Infection, 80(6), e14-e18. https:// doi.org/10.1016/j.jinf.2020.03.005.

Maughan-Brown, B., \& Venkataramani, A. S. (2017). Accuracy and determinants of perceived HIV risk among young women in South Africa. BMC Public Health, 18(1), 1-9. https://doi.org/10. 1186/s12889-017-4593-0.

Marková, I. (2007). Social identities and social representations. In Social representations and identity (pp. 215-236). Palgrave Macmillan.

Menezes, C. R., Sanches, C., \& Chequer, F. M. D. (2020). Efetividade e toxicidade da cloroquina e da hidroxicloroquina associada (ou não) à azitromicina para tratamento da COVID-19. O que sabemos até o momento? Journal of Health \& Biological Sciences, 8(1), 1-9. https://doi.org/10. 12662/2317-3076jhbs.v8i1.3206.p1-9.2020.

Moscovici, S. (1961). La psychanalyse, son image et son public [Psychoanalysis, its image and its public]. Presses Universitaires de France.

Moscovici, S. (1976). Social influence and social change (Vol. 10). Academic Press.

Moscovici, S. (1978). A representação social da psicanálise. Zahar editores.

Moscovici, S. (1981). On social representations. Perspectives on everyday understanding. In J. Forgas (Ed.), Social Cognition (pp. 181-209). Academic Press.

Negura, L. (2016). L'intervention en sciences humaines: l'importance des représentations. PUL.

Nunes, V. M. A. N., Machado, F. C. A., Morais, M. M., Costa, L. A., Nascimento, I. C. S., Nobre, T. T. X., \& Silva, M. E. (2020). COVID-19 e o cuidado de idosos: recomendações para instituições de longa permanência. EDUFRN Retrieved from: https://repositorio.ufrn.br/jspui/handle/12345 $6789 / 28754$.

Páez, D., \& Pérez, J. A. (2020). Social representations of COVID-19. International Journal of Social Psychology, 35(3), 600-610. https://doi.org/10.1080/02134748.2020.1783852. 
Paula, F. R., \& da Silva Mello, M. G. (2020). Análise de Redes Sociais: a formação de grupos do Facebook frente à epidemia da COVID-19 no Brasil. VITTALLE-Revista de Ciências da Saúde, 32(1), 32-42. https://doi.org/10.14295/vittalle.v32i1.11406.

Plohl, N., \& Musil, B. (2020). Modeling compliance with COVID-19 prevention guidelines: The critical role of trust in science. Psychology, Health \& Medicine, 1-12. https://doi.org/10.1080/13548506. 2020.1772988 .

Ratinaud, P. (2009). IRAMUTEQ: Interface de R pour les Analyses Multidimensionnelles de Textes et de Questionnaires [Computer software]. Retrieved from: http://www.iramuteq.org

Ratinaud, P., \& Marchand, P. (2015). Des mondes lexicaux aux représentations sociales. Une première approche des thématiques dans les débats à l'Assemblée nationale (1998-2014). Mots. Les langages du politique, (108), 57-77. https://doi.org/10.4000/mots.22006.

Souza, G. R.e., Trota, L. F., Leite, S. K., Guerra, D. P., Santos, A. P., Arruda, M. P., Tonholo do Couto, L., \& de Castro Cunha, R. M. (2020). Hidroxicloroquina no tratamento da Covid-19: uma revisão narrativa. Revista Eletrônica Acervo Saúde, (46), e4029. https://doi.org/10.25248/reas.e4029.2020.

Tavares, L. P., de Oliveira Júnior, F. L., \& Magalhães, M. (2020). Analysis of President Jair Bolsonaro's speeches in the midst of the pandemic: is the coronavirus just a "little flu"? Research, Society and Development, 9(7). https://doi.org/10.33448/rsd-v9i7.4469.

Taylor, S. (2019). The psychology of pandemics: Preparing for the next global outbreak of infectious disease. Cambridge Scholars Publishing.

Wachelke, J., Wolter, R., \& Rodrigues Matos, F. (2016). Efeito do tamanho da amostra na análise de evocações para representações sociais. Liberabit, 22(2), 153-160. https://doi.org/10.24265/liberabit. 2020.v26n2.

Wagner, W. (1995). Social representations, group affiliation, and projection: Knowing the limits of validity. European Journal of Social Psychology, 25(2), 125-139. https://doi.org/10.1002/ejsp.24202 50202.

World Health Organization. (2020). Coronavírus disease (COVID-19) Pandemic [site]. Retrieved from: https://www.who.int/emergencies/diseases/novel-coronavirus-201

\title{
Authors and Affiliations
}

\section{Andréia Isabel Giacomozzi ${ }^{1}$ (1) Adriano Rozendo² ${ }^{2}$. Andréa Barbará da Silva Bousfield ${ }^{1}$ (1) Maiara Leandro ${ }^{1}$ (i) . Juliana Gomes Fiorott ${ }^{1}\left[{ }^{(1)}\right.$. Anderson da Silveira ${ }^{3}[$}

\author{
Adriano Rozendo \\ rozendoadriano@uol.com.br \\ Andréa Barbará da Silva Bousfield \\ andreabs@gmail.com \\ Maiara Leandro \\ maiaraleandro_psico@hotmail.com \\ Juliana Gomes Fiorott \\ juliana.gomesfiorott@gmail.com \\ Anderson da Silveira \\ andersonsilveirapessoal@gmail.com
}

1 Departamento de Psicologia e do Programa de Pós-Graduação em Psicologia, Laboratório de Psicologia Social e da Cognição - área psicologia social e cultura, linha Representações e práticas sociais-LACCOS, Universidade Federal de Santa Catarina, Felipe Schmidt n ${ }^{\circ}$ 1210/1206, Centro, Florianópolis, SC CEP: 88010-002, Brazil

2 Departamento de Psicologia, Universidade Federal de Rondonópolis, Rondonopolis, Brazil

3 Departamento de Psicologia, Laboratório de Psicologia Social e da Cognição - área psicologia social e cultura, linha Representações e práticas sociais-LACCOS, UNISUL, Florianopolis, Brazil 